\title{
Evaluasi Kelayakan Berdasarkan Aspek Geologi Lingkungan Untuk Penentuan TPA Kota Palangka Raya
}

\author{
Endah Kartika Susanti ${ }^{1,2^{*}}$, Salampak ${ }^{3}$, Hendrik Segah ${ }^{3}$ \\ ${ }^{1}$ Dinas Energi dan Sumberdaya Mineral Provinsi Kalimantan Tengah \\ ${ }^{2}$ Alumni Program Studi Magister Pengelolaan Sumberdaya Alam dan Lingkungan Universitas Palangka Raya \\ ${ }^{3}$ Dosen Program Studi Magister Pengelolaan Sumberdaya Alam dan Lingkungan Universitas Palangka Raya \\ *Korespondensi: Endah Kartika Susanti (Email: endahks@gmail.com)
}

\begin{abstract}
Regional feasibility analysis of landfill locations based on the environmental geology point is the initial selection in the planning of landfill sites. This research aims to assess the regional feasibility zones for landfill site in Palangka Raya city based on the environmental aspects. Observational examination and spatial analysis using geographic information system (GIS) were applied to ascertain the determination and limitation factors. The result shows that Palangka Raya could be categorized into 3 (three) zones in terms of its feasibility for the landfill area. Unsuitable zone covering an area of $165,936.69$ hectares or $58.12 \%$ of total area, followed by a moderately suitable zone of 782.25 hectares $(32.85 \%)$, and least suitable zone of $25,788.88$ hectares $(9.03 \%)$. The infeasible ones are located in districts of Sebangau and Pahandut, and some parts of Jekan Raya.
\end{abstract}

\section{Keywords}

Feasibility evaluation, environmental geology, landfill, GIS, suitability zone, Palangka Raya

\section{PENDAHULUAN}

Menurut UU 18 Tahun 2008 tentang Pengelolaan Sampah, tempat pemrosesan akhir (TPA) adalah tempat untuk memproses dan mengembalikan sampah ke media lingkungan secara aman bagi manusia dan lingkungan. Dalam menyelenggarakan pengelolaan sampah, Pemerintahan kabupaten/kota mempunyai kewenangan menetapkan lokasi tempat penampungan sementara, tempat pengolahan sampah terpadu, dan/atau tempat pemprosesan akhir sampah.

Penentuan lokasi TPA menjadi hal yang sangat penting karena terjadinya peningkatan volume sampah yang berhubungan dengan peningkatan laju jumlah penduduk dalam suatu kota (Al-Hanbali et al., 2011). Penentuan lokasi pemrosesan dan pemrosesan sampah telah menjadi tantangan besar bagi negara maju maupun negara berkembang di seluruh dunia sehingga menjadi perhatian serius bagi pengelola Pemerintah perkotaan, dimana dengan lajunya pertumbuhan penduduk maka lokasi pembuangan dan pemrosesan sampah menjadi sudah tidak mampu lagi menampung sampah yang ditimbun (Karthihea dan Yeshodha, 2016).
Kota Palangka Raya merupakan Ibukota Provinsi Kalimantan Tengah memiliki luas $2.678,51 \mathrm{~km}^{2}$ dengan jumlah penduduk sebanyak 275.661 jiwa dengan kepadatan penduduk rata-rata 112 jiwa tiap kilometer persegi (BPS Kota Palangka Raya, 2018). Untuk mengelola sampah di kota Palangka Raya, maka Pemerintah melalui Dinas Pasar dan Kebersihan kota Palangka Raya telah menetapkan lokasi TPA seluas 10 ha yang berada di $\mathrm{Km}$ 14 jalan Cilik Riwut Palangka Raya.

Menurut Asiaka (2018), volume sampah setiap hari yang mampu diangkut ke TPA Sampah Jalan Tjilik Riwut km. 14 mencapai $564 \mathrm{~m}^{3}$, sedangkan dalam komposisi sampah yang masuk TPA terdiri dari sisa makanan dan daun-daunan $(70,06 \%)$, plastik $(14,95 \%)$, kertas $(7,14 \%)$, kayu, kaca, logam/alumunium, karet, dan kain (5,46\%) serta lain-lain/campuran (2,39\%).

Pertumbuhan rata-rata laju penduduk di kota Palangka Raya adalah 3,1\% per tahun, maka bisa diperkirakan untuk 10-20 tahun maka akan terdapat 375.851 jiwa pada tahun 2027 dan 512.445 jiwa pada tahun 2037. Hal ini berarti akan menghasilkan sampah per hari 10 tahun ke depan adalah $768 \mathrm{~m}^{3}$ dan $1.042 \mathrm{~m}^{3}$ pada 20 tahun ke depan. 
TPA yang saat ini ada mempunyai lahan seluas 10 ha atau $10.000 \mathrm{~m}^{2}$ termasuk di dalamnya area pengelolaan dan kantor sarana prasarana. Dalam 10 tahun ke depan diperkirakan tumpukan sampah dapat mencapai 280.320 $\mathrm{m}^{3} /$ tahun atau $380.330 \mathrm{~m}^{3} /$ tahun dalam jangka waktu 20 tahun, sehingga lokasi TPA tidak mampu menampung dan mengolah sampah yang ada di kota Palangka Raya. Selain itu arah pertumbuhan tata ruang kota akan semakin luas dan lokasi TPA yang ada akan semakin dekat dengan pemukiman atau kegiatan masyarakat lainnya.

Berdasarkan hal tersebut maka Pemerintah kota Palangka Raya harus mempersiapkan lokasi lain yang lebih sesuai untuk dapat memenuhi kebutuhan pengelolaan sampah terhadap pertumbuhan kota Palangka Raya untuk 10 atau 20 tahun ke depan. Dalam mempersiapkan calon lokasi TPA maka diperlukan kajian kelayakan atau evaluasi kesesuaian lokasi.

Upaya untuk memenuhi kriteria kelayakan suatu TPA diperlukan adanya studi kelayakan untuk menentukan lokasi yang sesuai dengan standar yang telah diatur oleh Pemerintah melalui Standar Nasioanal Indonesia (SNI) 03 -3241-1994 yaitu tentang Tata Cara Pemilihan Lokasi TPA. Proses pemilihan Lokasi TPA idealnya melalui suatu tahapan penyaringan. Penyaringan tersebut paling tidak terdiri dari 3 tahapan, yaitu tahap awal atau regional, tahap individu atau penyisihan, dan tahap final atau penetapan. Dari tiga tahapan tersebut yang digunakan dalam penelitian ini adalah tahapan awal atau regional.

Analisis kelayakan regional lokasi TPA sampah didasarkan pada sudut pandang geologi lingkungan yang merupakan tahapan seleksi awal dalam perencanaan lokasi pemrosesan sampah. Peta kelayakan regional akan memberikan gambaran tentang wilayah yang baik dan tepat secara geologi lingkungan untuk menjadi lokasi pemrosesan sampah. Dalam pemilihan lokasi TPA, parameter yang dipertimbangkan dalam penilalan kelayakan lokasi TPA mencakup aspek geologi tata lingkungan sebagai parameter kelayakan fisik. Parameter lainnya (non-fisik) merupakan pembatas yang dinyatakan sebagai daerah-daerah tidak layak, seperti pemukiman, kawasan lindung dan infrastruktur penting.

Pemilihan lokasi TPA tanpa memperhatikan aspek geologi alamiah dapat menimbulkan persoalan yang rentan akan bencana alam. Wilayah yang berada pada zona kegempaan, rawan tsunami, zonasi erupsi gunungapi, rentan gerakan tanah tinggi akibat struktur tanah yang labil, zona-zona patahan aktif, kawasan limpahan banjir, dan lain-lain sedapat mungkin dihindari dipergunakan sebagai alternatif lokasi TPA.

Lokasi yang tidak mempertimbangkan parameterparameter yang digunakan dalam menentukan tata ruang berbasis geologi, dapat menimbulkan masalah di kemudian hari. Contoh kasus yakni penempatan TPA Alak di Kecamatan Alak Kota Kupang yang sudah dioperasikan sejak tahun 1998 tidak berbasis geologi sebab basement atau litologi lokasi TPA tersebut merupakan batugamping yang merupakan batuan yang bersifat porous sehingga dapat terjadi rembesan dan mencemari air tanah (Eki, 2014).

Dalam melakukan analisis kelayakan suatu lokasi TPA diperlukan alat bantu yang dapat mempermudah penentuan lokasi dengan metode tertentu, sehingga bisa didapatkan hasil yang akurat. Aplikasi Sistim Informasi Geografis (SIG) dapat membantu dalam menentukan lokasi TPA yang sesuai dengan persyaratan teknis dengan meng-overlay peta tematik untuk mendapatkan TPA yang sesuai (Sener et al., 2011; Kenate, 2017). Menurut Imtiaz (2011) dalam Haryanto (2018), SIG telah terbukti berguna dan efektif dalam menentukan lahan yang sesuai dalam membangun lingkungan sesuai tujuan tertentu.

Evaluasi kelayakan TPA berdasarkan aspek geologi lingkungan mempergunakan SIG akan memberikan gambaran kelayakannya terhadap beberapa lokasi di kota Palangka Raya sehingga dapat menjadi pilihan bagi Pemerintah kota Palangka Raya dalam menentukan lokasi yang sesuai untuk TPA Sampah. Selanjutnya penelitian ini dapat dipertimbangkan sebagai bahan masukan bagi kebijakan Pemerintah Kota Palangka Raya dalam membuat pertimbangan dalam pengelolaan maupun rencana penentuan lokasi TPA di masa mendatang.

Penelitian ini bertujuan untuk menentukan zona kelayakan regional berdasarkan aspek geologi lingkungan dan menentukan faktor penentu dan pembatas lokasi TPA kota Palangka Raya.

\section{METODOLOGI}

Metode yang digunakan dalam penelitian ini adalah metode penelitian observasi dengan melakukan analisa spasial dengan mempergunakan sistem informasi geografis dan cek lapangan. Data-data diperoleh dari instansi-instansi pemerintah maupun studi literatur serta pengecekan langsung ke lapangan sebagai pembanding. Data-data berdasarkan parameter-parameter tersebut saling ditumpang-tindihkan satu sama lain sehingga hasil akhirnya bisa diperoleh suatu zonasi kelayakan lahan TPA secara regional.

Data spasial, skala dan sumbernya disajikan pada Tabel 1. Pada lokasi existing TPA Sampah kota Palangka Raya dilakukan pengambilan sample tanah sebagai verifikasi kesesuain zona kelayakan yang telah dibuat. Data yang akan diambil disajikan pada Tabel 2 .

Metodelogi detail setiap tahapan kegiatan sesuai tujuan penelitian akan diuraikan pada Tabel 3 .

Metode analisa data dilakukan dengan cara melakukan evaluasi terhadap setiap komponen parameter geologi lingkungan dan komponen pembatas dari wilayah kota Palangka Raya. Teknik pengolahan dan analisa data yang digunakan dalam penelitian ini adalah menggunakan analisa deskriptif dengan mengunakan aplikasi sistem informasi geografis dengan cara melakukan overlay dan buffering peta-peta tematik. 
Tabel 1. Data spasial, skala dan sumbernya

\begin{tabular}{|c|c|c|}
\hline Jenis Data & Skala & Sumber Data \\
\hline $\begin{array}{l}\text { Peta Rupa Bumi Lembar Palangka Raya 1613-64 } \\
\text { dan Lembar Tangkiling 1614-32 }\end{array}$ & 1: 50.000 & Badan Informasi Geospasial. 2013 \\
\hline Peta Geologi Lembar Palangka Raya & 1: 250.000 & $\begin{array}{l}\text { Pusat Penelitian dan Pengembangan Geologi } \\
\text { Bandung. } 1995\end{array}$ \\
\hline $\begin{array}{l}\text { Peta Hidrogeolgi Indonesia lembar Palangka Raya } \\
\text { dan lembar Pematang Limau }\end{array}$ & 1: 100.000 & $\begin{array}{l}\text { Pusat Air Tanah dan Geologi Lingkungan. Badan } \\
\text { Geologi. Bandung, } 2016\end{array}$ \\
\hline $\begin{array}{l}\text { Peta konservasi Air Tanah cekungan air tanah } \\
\text { Palangka Raya - Banjarmasin II, Kalimantan }\end{array}$ & 1: 250.000 & $\begin{array}{l}\text { Pusat Air Tanah dan Geologi Lingkungan. Badan } \\
\text { Geologi. Bandung, } 2013\end{array}$ \\
\hline $\begin{array}{l}\text { Peta Zona Kerentanan Gerakan Tanah Provinsi } \\
\text { Kalimantan Tengah }\end{array}$ & 1: 250.000 & $\begin{array}{l}\text { Pusat Vulkanologi dan Mitigasi Bencana Geologi. } \\
\text { Badan Geologi. Bandung, } 2018\end{array}$ \\
\hline $\begin{array}{l}\text { Peta Kelerengan, Pengunaan Lahan, Peta Curah } \\
\text { hujan, Peta Rawan Banjir, Peta administratif, Peta } \\
\text { Jaringan Jalan }\end{array}$ & 1: 250.000 & $\begin{array}{l}\text { Perda Provinsi Kalimantan Tengah Nomor } 5 \text { tahun } \\
2015 \text { tentang Rencana Tata Ruang Wilayah Provinsi } \\
\text { Kalimantan Tengah Tahun 2015-2035 }\end{array}$ \\
\hline
\end{tabular}

Tabel 2. Parameter dan metode uji sifat fisik tanah

\begin{tabular}{cllc}
\hline No & \multicolumn{1}{c}{ Parameter } & \multicolumn{1}{c}{ Tujuan Analisa } & Standar \\
\hline 1. & Kadar air & $\begin{array}{l}\text { Mengetahui kadar air suatu sampel tanah, yaitu perbandingan } \\
\text { antara berat air yang terkandung dalam tanah dengan berat butir } \\
\text { kering tanah tersebut yang dinyatakan dalam persen. }\end{array}$ & ASTM D 2216 \\
2. & $\begin{array}{l}\text { Berat jenis (spesific } \\
\text { gravity) }\end{array}$ & $\begin{array}{l}\text { Menentukan kepadatan massa butiran atau partikel tanah yaitu } \\
\text { perbandingan antara berat butiran tanah dan berat air suling } \\
\text { dengan volume yang sama pada suhu tertentu. }\end{array}$ & ASTM D 854 \\
3. & $\begin{array}{l}\text { Berat volume basah } \\
\text { (bulk density) }\end{array}$ & $\begin{array}{l}\text { Menentukan berat volume basah tanah asli yang mana adalah } \\
\text { perbandingan antara berat tanah asli seluruhnya dengan isi } \\
\text { tanah asli seluruhnya. }\end{array}$ & ASTM D 2937 \\
\hline
\end{tabular}

Tabel 3. Ringkasan metode penelitian

\begin{tabular}{|c|c|c|c|c|}
\hline No & Tujuan Penelitian & Jenis Data & Teknik Analisis & Luaran \\
\hline 1. & $\begin{array}{l}\text { Mendapatkan zona } \\
\text { kelayakan } \\
\text { berdasarkan aspek } \\
\text { geologi lingkungan } \\
\text { untuk penentuan } \\
\text { lokasi TPA Kota } \\
\text { Palangka Raya }\end{array}$ & $\begin{array}{l}\text { Peta Kelas Kelayakan terhadap } \\
\text { - Litologi } \\
\text { - kemiringan lereng } \\
\text { - Gerakan tanah } \\
\text { - Curah hujan } \\
\text { - Hidrogeologi } \\
\text { - Penggunaan Lahan }\end{array}$ & $\begin{array}{l}\text { Penilaian dan } \\
\text { pembobotan }\end{array}$ & $\begin{array}{l}\text { Zona kelayakan TPA } \\
\text { kota Palangka Raya } \\
\text { yang sesuai } \\
\text { berdasarkan aspek } \\
\text { geologi lingkungan }\end{array}$ \\
\hline 2 & $\begin{array}{l}\text { Menentukan faktor } \\
\text { penentu dan } \\
\text { pembatas kelayakan } \\
\text { TPA sampah kota } \\
\text { Palangka Raya } \\
\text { berdasarkan aspek } \\
\text { geologi lingkungan }\end{array}$ & $\begin{array}{l}\text { Peta Komponen Penyisih } \\
\text { - Jarak terhadap sungai dan danau } \\
\text { - Jarak terhadap zona patahan aktif } \\
\text { - Daerah bahaya Letusan gunung api } \\
\text { - Banjir berkala } \\
\text { - Jarak dari garis pantai pada daerah } \\
\text { landai } \\
\text { - Daerah lindung } \\
\text { - Jarak terhadap Pemukiman } \\
\text { - Jarak dari jalan utama dan kereta } \\
\text { - Japi }\end{array}$ & $\begin{array}{l}\text { Analisa spasial } \\
\text { sistem informasi } \\
\text { geografis dengan } \\
\text { cara skoring, } \\
\text { overlay dan } \\
\text { buffering }\end{array}$ & $\begin{array}{l}\text { Faktor penentu dan } \\
\text { pembatas lokasi TPA } \\
\text { kota Palangka Raya }\end{array}$ \\
\hline
\end{tabular}


Berikut adalah urutan langkah yang dikerjakan dalam melakukan analisis data:

1. Tahap Pengumpulan Data

Dalam tahap ini dikumpulkan data-data yang diperlukan dan dibutuhkan untuk kemudian diolah dan diproses. data-data yang ada dibagi menjadi data komponen yang dinilai yaitu data-data yang mewakili aspek geologi lingkungan dan data komponen penyisih.

2. Tahap Analisis

Dalam analisis kelayakan aspek-aspek yang dipertimbangkan dalam penilaian kelayakan lahan TPA mencakup aspek geologi lingkungan dan non-geologi. Beberapa parameter dikelompokkan sesuai tingkat kelayakannya menjadi komponen penentu dan komponen penyisih. Untuk komponen penentu nilai kepentingannya diberikan pengharkatan untuk dapat menentukan nilai tingkat kesesuaian lahan untuk TPA. Pengharkatan merupakan pemberikan skor yang didasarkan pada logika besar kecilnya pengaruh dari setiap kelas terhadap aspek penting dalam penentuan kesesuain lahan.

Tabel 4 menunjukkan pengharkatan pada masing masing parameter pada faktor penentu pada aspek geologi lingkungan.

Klasifikasi kelas kesesuaian lahan dihitung menggunakan rumus sebagai berikut:

$$
\begin{aligned}
& K i=\frac{\sum \text { harkat tertinggi }-\sum \text { harkat terendah }}{\sum \text { Kelas yang diinginkan }} \\
& K i=\frac{180-52}{4}=32
\end{aligned}
$$

\begin{tabular}{|c|c|c|c|c|c|c|c|}
\hline No. & Komponen & & Kelas & Nilai & Bobot & Skor & Keterangan \\
\hline \multirow[t]{5}{*}{1} & \multirow[t]{5}{*}{ Litologi } & $a$ & $\begin{array}{l}\text { Batu lempung, batu lanau, } \\
\text { tufa halus, napal, lempung, } \\
\text { batuan beku masif }\end{array}$ & 5 & \multirow[t]{5}{*}{10} & 50 & \multirow[t]{2}{*}{$\begin{array}{l}\text { Jenis batuan sangat berperan dalam } \\
\text { meredam pencemaran dari air lindi, } \\
\text { kemampuan peredaman mencakup permea- } \\
\text { bilitas, daya infiltrasi, absorsi, dll. }\end{array}$} \\
\hline & & B & $\begin{array}{l}\text { Tufa kasar, lanau, serpih, } \\
\text { batuan metamorf dan } \\
\text { batuan beku terkekarkan }\end{array}$ & 4 & & 40 & \\
\hline & & $\mathrm{C}$ & $\begin{array}{l}\text { Batu pasir, konglomerat dan } \\
\text { breksi sedimen }\end{array}$ & 3 & & 30 & $\begin{array}{l}\text { Material batuan berbutir halus seperti batu- } \\
\text { lempung, napal, mempunyai daya peredam } \\
\text { yang lebih tinggi jika dibandingkan dengan } \\
\text { material besar/kristalin. }\end{array}$ \\
\hline & & $\mathrm{d}$ & $\begin{array}{l}\text { Konglomerat vulkanik, tufa } \\
\text { batu apung, breksi volkanik }\end{array}$ & 2 & & 20 & $\begin{array}{l}\text { Batuan yang telah padu mempunyai daya } \\
\text { peredam lebih tinggi jika dibandingkan den- } \\
\text { gan batuan lepas. }\end{array}$ \\
\hline & & e & $\begin{array}{l}\text { Pasir, tanah organik, batu } \\
\text { gamping dan endapan lahar }\end{array}$ & 1 & & 10 & \\
\hline 2 & $\begin{array}{l}\text { Kontur air } \\
\text { tanah }\end{array}$ & $\begin{array}{l}a \\
b \\
c \\
d\end{array}$ & $\begin{array}{l}0-10 \text { meter } \\
10-15 \text { meter } \\
15-20 \text { meter } \\
20-25 \text { meter }\end{array}$ & $\begin{array}{l}2 \\
3 \\
4 \\
5\end{array}$ & 10 & $\begin{array}{l}20 \\
30 \\
40 \\
50\end{array}$ & $\begin{array}{l}\text { Semakin dangkal muka air tanah, semakin } \\
\text { mudah pencemaran terjadi. } \\
\text { Daerah dengan kedalaman muka air tanah } \\
\text { kurang dari } 3 \text { m, dianggap tidak layak untuk } \\
\text { lokasi TPA sampah. }\end{array}$ \\
\hline 3 & $\begin{array}{l}\text { Kemiringan } \\
\text { lereng }\end{array}$ & $\begin{array}{l}a \\
b \\
c \\
d\end{array}$ & $\begin{array}{l}0-8 \% \\
8-15 \% \\
15-25 \% \\
25-35 \%\end{array}$ & $\begin{array}{l}5 \\
4 \\
3 \\
2\end{array}$ & 6 & $\begin{array}{l}30 \\
24 \\
18 \\
12\end{array}$ & $\begin{array}{l}\text { Semakin terjal suatu daerah semakin sulit } \\
\text { pekerjaan kontruksi dan operasional TPA. } \\
\text { Semakin terjal suatu daerah semakin sulit } \\
\text { pekerjaan konstruksi dan pengoperasian-nya. } \\
\text { Daerah dengan kemiringan }>20 \% \text { tidak layak } \\
\text { untuk lokasi TPA. }\end{array}$ \\
\hline 4 & Curah hujan & $\begin{array}{l}a \\
b \\
c \\
d \\
e\end{array}$ & $\begin{array}{l}0-1000 \mathrm{~mm} \\
1000-2000 \mathrm{~mm} \\
2000-3000 \mathrm{~mm} \\
3000-4000 \mathrm{~mm} \\
>4000 \mathrm{~mm}\end{array}$ & $\begin{array}{l}5 \\
4 \\
3 \\
2 \\
1\end{array}$ & 4 & $\begin{array}{l}20 \\
16 \\
12 \\
8 \\
4\end{array}$ & $\begin{array}{l}\text { Besarnya curah hujan berkaitan dg.tingkat } \\
\text { kesulitan penyediaan sarana TPA yaitu parit } \\
\text { pembuang air larian, kolam pengumpul lindi } \\
\text { dan oksidasi. } \\
\text { Semakin tinggi curah hujan semakin tinggi } \\
\text { pula tingkat kesulitannya. }\end{array}$ \\
\hline 5 & $\begin{array}{l}\text { Potensi } \\
\text { gerakan } \\
\text { tanah }\end{array}$ & $\begin{array}{l}a \\
b \\
c\end{array}$ & $\begin{array}{l}\text { Sangat rendah } \\
\text { Rendah } \\
\text { Menengah }\end{array}$ & $\begin{array}{l}5 \\
3 \\
1\end{array}$ & 3 & $\begin{array}{l}15 \\
9 \\
3\end{array}$ & $\begin{array}{l}\text { Daerah rawan gerakan tanah dianggap tidak } \\
\text { layak menjadi TPA karena gerakan tanah } \\
\text { dapat merusak kontruksi TPA dan } \\
\text { mengganggu kegiatan operasionalnya. } \\
\text { Suatu daerah dianggap rawan gerakan tanah } \\
\text { jika mempunyai kerentanan gerakan tanah } \\
\text { sedang sampai tinggi. }\end{array}$ \\
\hline 6 & $\begin{array}{l}\text { Penggunaan } \\
\text { lahan } \\
\text { (Tumbuh- } \\
\text { tumbuhan) }\end{array}$ & $\begin{array}{l}a \\
b \\
c \\
d\end{array}$ & $\begin{array}{l}\text { Pemukiman /perairan darat } \\
\text { persawahan } \\
\text { Kebun/hutan } \\
\text { Tegalan/ladang,sawah } \\
\text { tadah hujan/pertanian tanah } \\
\text { kering } \\
\text { Semak belukar/tanah } \\
\text { terbuka }\end{array}$ & $\begin{array}{l}0 \\
2 \\
3 \\
4 \\
5\end{array}$ & 3 & $\begin{array}{c}0 \\
6 \\
9 \\
12 \\
15\end{array}$ & \\
\hline
\end{tabular}

Table 4. Parameter, bobot dan nilai pada faktor penentu aspek geologi lingkungan 
Berdasarkan rumus di atas diperoleh kelas interval 32 dengan jumlah kelas yang diinginkan adalah 4, maka akan didapatkan kelas kesesuaian lahan sebagaimana disajikan pada Tabel 5.

Tabel 5. Zona tingkat kesesuaian lahan

\begin{tabular}{ccc}
\hline No & Nilai & Zona kelayakan \\
\hline 1 & $<84$ & Tidak layak sebagai TPA \\
2 & $84-16$ & layak rendah sebagai TPA \\
3 & $116-148$ & Layak sedang sebagai TPA \\
4 & $148-180$ & Layak tinggi sebagai TPA \\
\hline
\end{tabular}

Pada tahap penyisih, analisa yang dilakukan terhadap paramater adalah dengan melakukan teknik overlay dan buffering sesuai jarak yang sudah ditentukan sesuai batas jarak minimum modifikasi dari ketentuan dari SNI 033241-1994 tentang Tata cara pemilihan lokasi tempat pembuangan akhir sampah dan aspek geologi lingkungan.

Dalam penelitian ini penyisih dibagi menjadi dua menjadi penyisih geologi (Tabel 6) dan penyisih nongeologi (Tabel 7) yang merupakan daerah terlarang untuk dikembangkan. Daerah terlarang adalah daerah yang terkait dengan pembatas geologi berupa daerah mempunyai resiko terjadinya bencana geologi sangat besar, contohnya pada zona sesar aktif atau pada wilayah yang sangat berdekatan dengan gunung api aktif. Penyisih non geologi adalah daerah yang telah ditetapkan sebagai wilayah konservasi atau lindung, atau dapat juga suatu wilayah mempunyai periode tertentu mengalami perubahan secara alami seperti banjir tahunan atau pasang surut.

\section{HASIL EVALUASI KELAYAKAN TPA}

\subsection{Aspek Geologi Lingkungan \\ Aspek Litologi}

Satuan Batuan yang ada di wilayah kota Palangka Raya berdasarkan sebarannya didominasi oleh Formasi Dahor yang adalah berupa konglomerat yang tertanam dalam massa pasir dan berseling dengan batu pasir dan batu lempung. Sedangkan berdasarkan peta sebaran tanah dari Peraturan daerah Provinsi Kalimantan Tengah Nomor 5 tahun 2015 tentang Rencana Tata Ruang Wilayah Provinsi Kalimantan Tengah Tahun 2015-2035 kota Palangka Raya didominasi oleh jenis tanah Podsol yang digambarkan mempunyai tekstur cenderung berpasir hingga lempung (Tabel 8). Sehingga berdasarkan satuan batuan penyusun dari formasi geologi yang ada, pembagian dan skoring jenis litologi yang ada di kota Palangka Raya menggunakan batuan penyusun yang menjadi bagian dari formasi geologi yang ada.

Jenis batuan sangat berperan dalam meredam pencemaran dari air lindi, kemampuan meredam tersebut mencakup permeabilitas, daya infiltrasi, kemampuan absorsi batuan dan lain lain. Material batuan yang berbutir halus seperti batu lempung, napal dibandingkan batuan dengan material yang berbutir besar ataupun kristalin. Batuan yang telah padu atau padat lebih baik dari pada batuan yang masih bersifat lepas.

Tabel 6. Komponen penyisih geologi

\begin{tabular}{cllll}
\hline No & Komponen & Kriteria & Kelas & Keterangan \\
\hline 1 & Zona sesar aktif & Jarak $<100 \mathrm{~m}$ & Tidak Layak & Berkaitan dengan faktor \\
2 & Bahaya gunung api & Kawasan rawan III & Tidak Layak & \\
3 & Jarak dari garis pantai & $<500 \mathrm{~m}$ & Tidak Layak & \\
\hline
\end{tabular}

Tabel 7. Komponen penyisih non-geologi

\begin{tabular}{|c|c|c|c|c|}
\hline No & Komponen & Kriteria & Kelas & Keterangan \\
\hline 1 & Kawasan lindung & $\begin{array}{l}\text { Dalam kawasan } \\
\text { lindung }\end{array}$ & Tidak Layak & $\begin{array}{l}\text { Berkaitan dengan peraturan dan } \\
\text { perundang-undangan }\end{array}$ \\
\hline 2 & Jarak terhadap pemukiman & $<300 \mathrm{~m}$ & Tidak Layak & Estetika, bau dan lalat \\
\hline 3 & Daerah banjir berkala & $\begin{array}{l}\text { Periode ulang } 25 \\
\text { tahun atau lebih } \\
\text { sering }\end{array}$ & Tidak Layak & $\begin{array}{l}\text { Gangguan Mobilitas dan } \\
\text { kenyamanan, pencemaran, } \\
\text { wabah penyakit }\end{array}$ \\
\hline 4 & $\begin{array}{l}\text { Jarak dari jalan utama dan } \\
\text { kereta api }\end{array}$ & $<300 \mathrm{~m}$ & Tidak Layak & $\begin{array}{l}\text { Gannguan asap, bau dan } \\
\text { Estetika }\end{array}$ \\
\hline 5 & Jarak dari lapangan terbang & $<3000 \mathrm{~m}$ & Tidak Layak & $\begin{array}{l}\text { Kemungkinan gangguan asap } \\
\text { terhadap penerbangan }\end{array}$ \\
\hline 6 & $\begin{array}{l}\text { Jarak terhadap sungai dan } \\
\text { danau (termasuk jaringan } \\
\text { irigasi/drainase dan jaringan } \\
\text { air bersih PDAM) }\end{array}$ & $<150 \mathrm{~m}$ & Tidak Layak & $\begin{array}{l}\text { Proteksi air permukaan terhadap } \\
\text { pencemaran }\end{array}$ \\
\hline
\end{tabular}


Tabel 8. Skoring aspek litologi

\begin{tabular}{clccl}
\hline No & Formasi Geologi & Luas (ha) & Skoring & \multicolumn{1}{c}{ Keterangan } \\
\hline 1 & Formasi Dahor & $188.809,20$ & 20 & $\begin{array}{l}\text { Konglomerat coklat kehitaman, batupasir, } \\
\text { batulempung, batulempung karbonan } \\
\text { mengandung lignit }\end{array}$ \\
2 & Alluvium & $95.066,21$ & 10 & $\begin{array}{l}\text { Gambut, pasir lepas, kerakal, kerikil, lempung, } \\
\text { lempung kaolinan dan sisa tumbuhan } \\
\text { Batuan plutonik dengan komposisi granit- } \\
\text { granodiaorite }\end{array}$ \\
\hline 3 & Batuan Beku & $1.632,45$ & 50 & \\
\hline
\end{tabular}

\section{Aspek Hidrogeologi}

Berdasarkan data kontur air tanah dari Peta konservasi Air Tanah cekungan air tanah Palangka RayaBanjarmasin II, Kalimantan tahun 2013 yang dibuat oleh Pusat Sumber Daya Air dan Geologi Tata Lingkungan dan data kontur air tanah dari Laporan Akhir Survei Potensi Air Tanah di kota Palangkaraya, maka dibuat peta kontur air tanah kota Palangka Raya yang kemudian diberikan skoring (Tabel 9).

Pada lokasi TPA existing, kedalaman sumur milik masyarakat sekitar TPA berdasarkan hasil wawancara adalah berkisar antara 10-25 meter. Kedalaman muka air tanah dari sumur sumur milik masyarakat tidak dapat diukur, karena biasanya telah ditutup dengan semen. Pada sumur pantau yang ada berjarak kurang lebih 100 $\mathrm{m}$ dari TPA dengan pemukiman terdekat kedalaman muka air tanah yang dapat diukur dengan menggunakan alat water level meter SOLINST 101 P7 adalah 11,5 meter dari permukaan tanah.

\section{Aspek Kemiringan Lereng}

Kemiringan lereng dapat tercermin dari keadaan topografi kota Palangka Raya yang relatif datar. Berdasarkan analisa peta topografi dapat dilihat kemiringan lereng kota Palangka Raya terbagi menjadi daerah dataran dan perbukitan bergelombang lemah dengan kemiringan lereng kurang dari 25\%. Daerah yang mempunyai kelerengan lebih dari $25 \%$ hanya berada di daerah Bukit Tangkiling seluas 124 ha.

Telaah aspek kemiringan lereng dalam penentuan TPA sampah dapat berkaitan dengan potensi gerakan tanah, karena salah satu faktor yang dapat mempengaruhi terjadinya gerakan tanah adalah kemiringan lereng. Selain itu lokasi dengan lereng yang terjal akan menyulitkan dalam pengelolaan sampah dalam TPA. Sehingga semakin landai maka akan semakin baik.

Kota Palangka Raya pada tingkat kelerengan 0-8\% mencapai luasan 285.069,26 ha dari luas total kota Palangka Raya sendiri. Hasil analisa peta kelerengan kota Palangka Raya disajikan pada Tabel 10.

\section{Aspek Potensi Gerakan Tanah}

Gerakan tanah merupakan salah satu proses geologi yang terjadi akibat interaksi beberapa kondisi antara lain keadaan geomorfologi, struktur geologi, hidrologi dan tata guna lahan. Kondisi tersebut saling berpengaruh sehingga mewujudkan kondisi lereng yang cenderung bergerak (Karnawati, 2007).

Berdasarkan Peta Rawan Bencana Gerakan Tanah yang dibuat diterbitkan oleh Pusat Vulkanologi dan Mitigasi Bencana Geologi dari Badan Geologi, hasil klasifikasi untuk wilayah kota Palangka Raya berada

Tabel 9. Skoring aspek hidrogeologi

\begin{tabular}{ccccl}
\hline No & $\begin{array}{c}\text { Zona Kontur } \\
\text { Air Tanah (m.aml) }\end{array}$ & Luas (ha) & Skoring & \multicolumn{1}{c}{ Keterangan } \\
\hline 1 & $5-10$ & $73.667,49$ & 16 & $\begin{array}{l}\text { Semakin dangkal muka air tanah, semakin } \\
\text { mudah terjadi pencemaran terjadi. }\end{array}$ \\
2 & $10-15$ & $38.529,44$ & 24 & Kedalaman muka air tanah kurang dari 3 \\
meter tidak layak menjadi lokasi TPA.
\end{tabular}

Tabel 10. Skoring aspek kemiringan lereng

\begin{tabular}{ccccl}
\hline No & Tingkat kelerengan & Luas (ha) & Skoring & \multicolumn{1}{c}{ Keterangan } \\
\hline 1 & $0 \%-8 \%$ & $285.069,26$ & 30 & Semakin terjal suatu daerah semakin sulit \\
2 & $8 \%-15 \%$ & 313,26 & 24 & pekerjaan konstruksi dan pengelolaan TPA. \\
3 & $15 \%-25 \%$ & 123,04 & 18 & Daerah dengan kemiringan lereng lebih \\
4 & $25 \%-45 \%$ & 2,26 & 12 & \\
\hline
\end{tabular}


dalam 2 (dua) zona yaitu zona kerentanan gerakan tanah sangat rendah dan Zona kerentanan gerakan tanah rendah. Pada kedua zona ini jarang terjadi atau bahkan hampir tidak pernah terjadi gerakan tanah, bila terjadi gerakan tanah hanya berdimensi kecil dan mungkin dapat terjadi pada tebing sungai.

Hasil analisa peta kelerengan kota Palangka Raya disajikan pada Tabel 11. Daerah rawan gerakan tanah dianggap tidak layak menjadi TPA Sampah karena dapat merusak konstruksi dan mengganggu kegiatan operasional pengelolaan sampah. Suatu daerah dianggap mempunyai kerentanan tanah bila dalam klasifikasi sedang sampai tinggi.

\section{Aspek Curah Hujan}

Aspek Curah hujan selain merupakan salah satu faktor penentu dalam analisa zona gerakan tanah juga menjadi faktor penting dalam pemilihan lokasi TPA terkait dengan jumlah curah hujan yang dapat mempengaruhi tingkat kesulitan penyediaan sarana TPA sampah yaitu parit pembuang air larian, kolam pengumpul leachate dan terjadinya oksidasi. Semakin tinggi curah hujan semakin tinggi pula tingkat kesulitannya. Berdasarkan data analisa peta curah hujan dari BMKG stasiun Palangka Raya dan memperhatikan jumlah hari hujan didapatkan bahwa curah hujan tertinggi dapat mencapai $5400 \mathrm{~mm}$ per tahun terjadi terutama pada kecamatan Pahandut, Sebangau dan sebagian Jekan Raya, sedangkan pada sebagian kecamatan Bukit Batu dan Rakumpit curah hujan mencapai 3000 mm/tahun, secara keseluruhan curah hujan di kota Palangka Raya per tahun cukup tinggi yaitu sekitar $4.200 \mathrm{~mm}$ per tahun.

Sesuai dengan klasifikasi kelas untuk komponen curah hujan pada metode studi maka kelas klasifikasi untuk curah hujan tertinggi di kota Palangka Raya akan menjadi 2 (Tabel 12).

\section{Aspek Pengunaan Lahan}

Aspek penggunaan lahan yang diberi skoring pada tahap ini adalah dengan melihat penggunaannya terhadap keberadaan tumbuh-tumbuhan yang ada. Penggunaan lahan dibagi menjadi 5 bagian yaitu semak belukar/tanah terbuka, tegalan/ladang, sawah tadah hujan/pertanian tanah kering, kebun/hutan, pemukiman/ perairan darat (Tabel 13). Peta yang digunakan untuk analisa pengguna lahan adalah Peta Penggunaan Lahan berdasarkan Peraturan Daerah Provinsi Kalimantan Tengah nomor 5 tahun 2015 tentang Rencana Tata Ruang Wilayah Provinsi Kalimantan Tengah Tahun 20152035 yang disesuaikan dengan aspek geologi lingkungan.

Tabel 11. Skoring potensi gerakan tanah

\begin{tabular}{clccl}
\hline No & $\begin{array}{c}\text { Zona Kerentanan } \\
\text { Gerakan Tanah }\end{array}$ & Luas (ha) & Skoring & Keterangan \\
\hline 1 & Rendah & $188.650,47$ & 30 & $\begin{array}{l}\text { Jarang terjadi gerakan tanah jika tidak mengalami } \\
\text { gangguan pada lereng, dan jika terdapat gerakan tanah } \\
\text { lama, lereng telah mantap kembali. }\end{array}$ \\
2 & Sangat rendah & $96.658,60$ & 24 & $\begin{array}{l}\text { Jarang atau hampir tidak pernah terjadi gerakan tanah, } \\
\text { baik gerakan tanah lama maupun gerakan tanah baru, } \\
\text { kecuali pada daerah tidak luas pada tebing sungai }\end{array}$ \\
& Danau & 18 & \\
\hline & Total & $\mathbf{2 8 5 . 5 0 7 , 8 2}$ & & \\
\hline
\end{tabular}

Tabel 12. Skoring curah hujan

\begin{tabular}{ccccl}
\hline No & Curah Hujan (mm) & Luas (ha) & Skoring & \multicolumn{1}{c}{ Keterangan } \\
\hline 1 & 3000 & $68.383,11$ & 12 & $\begin{array}{l}\text { Sebagian Rakumpit dan Bukit Batu } \\
\text { Sebagian beasr Rakumpit, Bukit Batu, Jekan Raya, } \\
2\end{array}$ \\
4200 & $145.886,53$ & 4 & $\begin{array}{l}\text { Sebagian kecil Sebangau } \\
\text { Pahandut, sebagian Jekan Raya dan Sebangau }\end{array}$ \\
3 & 5400 & $71.237,94$ & 4 & \\
\hline
\end{tabular}

Tabel 13. Skoring penggunaan lahan

\begin{tabular}{clrcc}
\hline No & \multicolumn{1}{c}{ Pengunaan Lahan } & Luas (ha) & Harkat & Skoring \\
1 & Pemukiman /perairan darat & $39.051,49$ & 0 & 0 \\
2 & Persawahan & 684,59 & 2 & 6 \\
3 & Kebun/hutan & $218.647,29$ & 3 & 9 \\
4 & Tegalan/ladang, sawah tadah hujan/pertanian tanah kering & $26.627,22$ & 4 & 12 \\
5 & Semak belukar/tanah terbuka & 498,61 & 5 & 15 \\
\hline \multicolumn{2}{c}{ Total } & $\mathbf{2 8 5 . 5 0 7 , 8 2}$ \\
\hline
\end{tabular}




\subsection{Aspek Pembatas}

Aspek pembatas dalam hal ini adalah aspek-aspek yang merupakan areal yang yang harus keluar dari penilaian lokasi kelayakan sebuah TPA dan membatasi lokasi tersebut berdasarkan jarak tertentu untuk dikategori menjadi zona layak dan zona tidak layak. Komponen pembatas secara geologi lingkungan terbagi menjadi pembatas geologi dan pembatas non geologi. Pembatas geologi adalah adalah daerah yang mempunyai resiko terjadinya bencana geologi sangat besar, contohnya pada zona sesar aktif atau pada wilayah yang sangat berdekatan dengan gunung api aktif. Penyisih non-geologi adalah daerah yang telah ditetapkan sebagai wilayah konservasi atau lindung, atau dapat juga suatu wilayah mempunyai periode tertentu mengalami perubahan secara alami seperti banjir tahunan atau pasang surut.

Kota Palangka tidak memilik kendala dalam hal pembatas geologi, karena tidak di dalam daerah zona sesar aktif, bahaya gunung api dan tidak berbatasan langsung dengan garis pantai (Tabel 15).

\section{PEMBAHASAN}

\subsection{Analisis Zona Kelayakan}

Berdasarkan hasil analisa SIG untuk aspek geologi lingkungan yang merupakan faktor penentu utama, Kota Palangka Raya memiliki 4 (empat) zona Kelayakan sebagaimana pada Tabel 16 dan Gambar 1.

Zona layak rendah dan Zona Layak sedang mempunyai memilik luas yang hampir sama yaitu masing -masing 47,11\% dan 49,88\%, terdapat lokasi layak tinggi yaitu sebagian kecil pada Kecamatan Bukit Batu yaitu daerah Bukit Tangkiling seluas 294,65 ha atau 0,1\% dari luas total kota Palangkaraya. Hal ini disebabkan karena skoring pada aspek litologi pada daerah Bukit Tangkiling yang merupakan satuan batuan beku mendapatkan nilai harkat yang tinggi.

Hasil skoring dan pembobotan dapat disebut sebagai tahap kelayakan pada tahap regional, kota Palangka Raya secara fisik memiliki 3 zona kelayakan seluas 277.221,37 ha atau mencapai $97,09 \%$ dari luas total dan zona tidak layak seluas $8.286,44$ ha atau seluas 2,91\%.

Tabel 16. Zona kelayakan berdasarkan aspek geologi

\begin{tabular}{clrr}
\hline No & Zona Kelayakan & Luas (ha) & \multicolumn{1}{c}{$\begin{array}{c}\text { Luas } \\
\text { (\%) }\end{array}$} \\
\hline 1 & Layak Rendah & $134.505,58$ & 47,11 \\
2 & Layak Sedang & $142.421,14$ & 49,88 \\
3 & Layak Tinggi & 294,65 & 0,10 \\
4 & Tidak Layak & $8.286,44$ & 2,90 \\
& Total & $\mathbf{2 8 5 . 5 0 7 , 8 2}$ & $\mathbf{1 0 0 , 0 0}$ \\
\hline
\end{tabular}

Zona yang termasuk zona layak secara fisik pada tahap ini mencapai 97,09\% dari luas total kota Palangka Raya dapat disebabkan oleh karena secara geologi, topografi dan hidrogeologi kota Palangka Raya relatif tidak memiliki perubahan dan variasi yang beragam. Dimana Litologi didominasi oleh formasi Dahor, topografi yang relatif datar dan kontur air yang juga relatif datar dan tidak terdapat daerah imbuhan kecuali daerah imbuhan yang diperkirakan ada di sekitar Bukit Tangkiling.

Tabel 14. Komponen pembatas geologi Kota Palangka Raya

\begin{tabular}{ccccc}
\hline No & \multicolumn{1}{c}{ Komponen } & \multicolumn{1}{c}{ Kriteria } & Kelas & \multicolumn{1}{c}{ Keterangan } \\
\hline 1 & Zona sesar aktif & Jarak $<100 \mathrm{~m}$ & Tidak Layak & Berdasarkan peta geologi tidak terdapat zona sesar aktif \\
2 & Bahaya gunung api & $\begin{array}{l}\text { Kawasan } \\
\text { Rawan III }\end{array}$ & Tidak Layak & $\begin{array}{l}\text { Berdasarkan peta geologi tidak terdapat kawasan } \\
\text { gunung api aktif }\end{array}$ \\
3 & Jarak dari garis pantai & $<500 \mathrm{~m}$ & Tidak Layak & $\begin{array}{l}\text { Berdasarkan peta geologi kota Palangka Raya berada }> \\
500 \mathrm{~m} \text { dari garis pantai }\end{array}$ \\
\hline
\end{tabular}

Tabel 15. Komponen pembatas non-geologi kota Palangka Raya

\begin{tabular}{|c|c|c|c|c|}
\hline No & Komponen & Kriteria & Kelas & Keterangan \\
\hline 1 & Kawasan lindung & Dalam kawasan lindung & Tidak Layak & Perda Provinsi \\
\hline 2 & Jarak terhadap pemukiman & $<300 \mathrm{~m}$ & Tidak Layak & Kalimantan Tengah \\
\hline 3 & Daerah banjir berkala & $\begin{array}{l}\text { Periode ulang } 25 \text { tahun } \\
\text { atau lebih sering }\end{array}$ & Tidak Layak & $\begin{array}{l}\text { Nomor } 5 \text { tanun } 2015 \\
\text { tentang Rencana Tata } \\
\text { Ruang Wilayah Provinsi }\end{array}$ \\
\hline 4 & Jarak dari jalan utama dan kereta api & $<300 \mathrm{~m}$ & Tidak Layak & Kalimantan Tengah \\
\hline 5 & Jarak dari lapangan terbang & $<3000 \mathrm{~m}$ & Tidak Layak & Tahun 2015-2035 \\
\hline 6 & $\begin{array}{l}\text { Jarak terhadap sungai dan danau } \\
\text { (termasuk jaringan irigasi/ drainase } \\
\text { dan jaringan air bersih PDAM) }\end{array}$ & $<150 \mathrm{~m}$ & Tidak Layak & \\
\hline
\end{tabular}




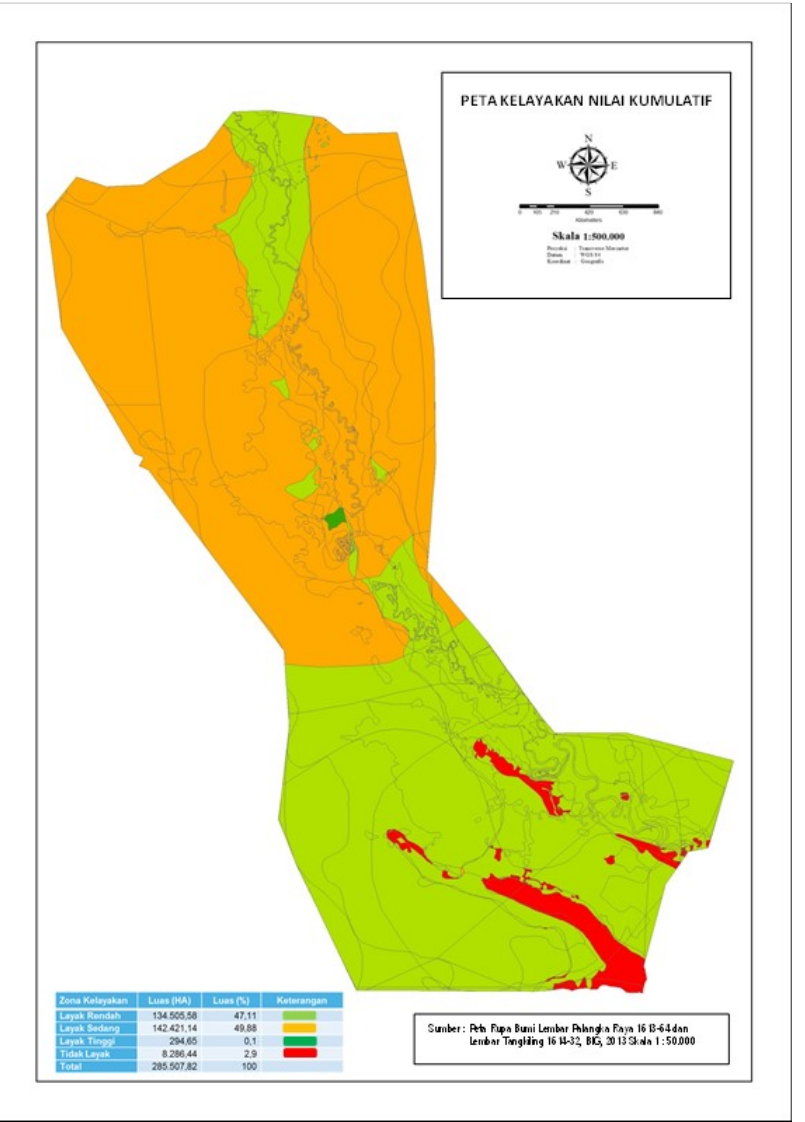

Gambar 1. Peta zona kelayakan nilai kumulatif (zona kelayakan berdasarkan aspek penentu atau aspek geologi lingkungan)

Secara geologi kota Kota Palangka Raya berada di atas lempeng tektonik yang stabil dan tidak memiliki struktur geologi yang dapat menyebabkan terjadinya bencana geologi, Formasi geologi yang ada didominasi oleh Formasi Dahor yang merupakan endapan berumur relatif muda yaitu diperkirakan berumur Miosen Tengah sampai Plistosen serta diendapan di lingkungan paralik. Secara topografi secara keseluruhan relatif datar dengan kemiringan lereng kurang dari $8 \%$.

Faktor yang cukup menentukan dalam pada proses tahapan regional adalah kontur air tanah dimana kota Palangka Raya berada dalam Cekungan Air Tanah yang melampar sangat luas dari Kalimantan Tengah sampai Kalimantan Selatan dengan daerah imbuhan berada di bagian utara di luar kota Palangkaraya. Kontur air tanah secara umum mengarah dari arah utara ke arah selatan. Berdasarkan data sebaran titik sumur bor masyarakat yang dikumpulkan oleh pihak ESDM provinsi Kalimantan Tengah di kota Palangka Raya memperlihat ada kecendrungan arah aliran tanah menuju ke daerah pusat kota Palangka Raya yaitu daerah kecamatan Pahandut

Pada tahap selanjutnya yaitu pada tahap penyisih, aspek pembatas yang digunakan untuk lokasi TPA Sampah terdapat 6 (enam) aspek yang dibagi menjadi 2 kategori yaitu:

1. Aspek pembatas geologi, berupa Zona Sesar Aktif, Zona Bahaya Gunung Api dan jarak dari garis pantai.
2. Aspek pembatas non geologi, berupa kawasan lindung, Jarak terhadap pemukiman, jarak terhadap jalan, jarak terhadap bandara, daerah rawan banjir berkala, Jarak terhadap sungai dan danau (termasuk jaringan irigasi/ drainase dan jaringan air bersih PDAM).

Hasil dari proses tahap penyisih berupa zona kelayakan regional (Gambar 2 dan Tabel 17) memperlihatkan kota Palangka Raya hanya memiliki 3 (tiga) Zona, yaitu Tidak Layak, Layak Rendah dan Layak Sedang. Sekitar 58,12\% yaitu seluas $165.936,69$ ha luas kota Palangka Raya adalah zona tidak layak sebagai lokasi TPA, meliputi daerah kecamatan Sebangau, Pahandut dan sebagian Jekan Raya dan 41,88\% adalah merupakan daerah zona yang layak untuk menjadi TPA sampah meliputi daerah pada kecamatan Bukit Batu, Rakumpit dan sebagian kecil Jekan Raya dan Pahandut.

Tabel 17. Hasil zona kelayakan tahap penyisih

\begin{tabular}{clrr}
\hline No & Zona Kelayakan & \multicolumn{1}{c}{ Luas (ha) } & \multicolumn{1}{c}{ Luas (\%) } \\
\hline 1 & Layak Rendah & $25.788,88$ & 9,03 \\
2 & Layak Sedang & $93.782,25$ & 32,85 \\
3 & Tidak Layak & $165.936,69$ & 58,12 \\
\hline & Total & $\mathbf{2 8 5 . 5 0 7 , 8 2}$ & $\mathbf{1 0 0 , 0 0}$ \\
\hline
\end{tabular}

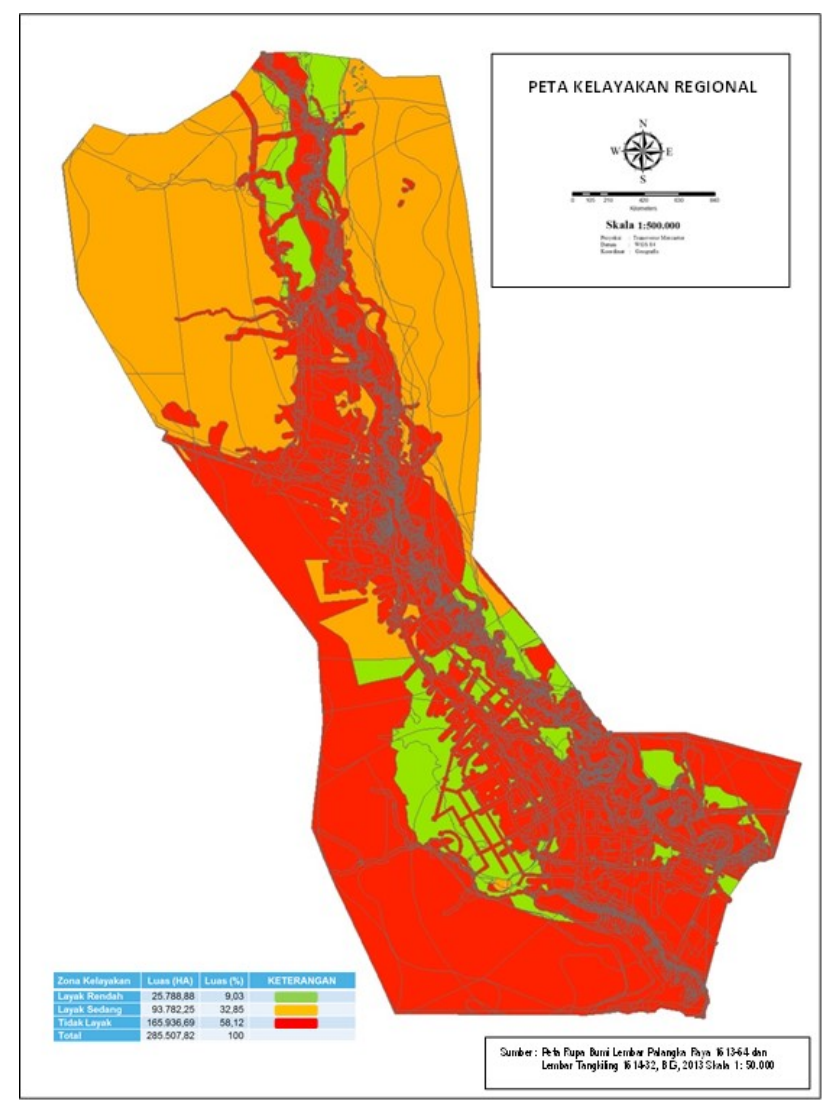

Gambar 2. Peta zona kelayakan regional 
Hasil akhir pada tahap penyisih mempelihatkan bahwa 58,12\% wilayah kota Palangka Raya tidak layak untuk dijadikan TPA Sampah. Aspek pembatas yang sangat mempengaruhi pada tahap penyisih adalah Aspek pembatas non geologi berupa kawasan lindung, Jarak terhadap pemukiman, jarak terhadap jalan, jarak terhadap bandara, daerah rawan banjir berkala, Jarak terhadap sungai dan danau (termasuk jaringan irigasi/ drainase dan jaringan air bersih PDAM).

\subsection{Hasil Penelitian Serupa}

Pada hasil penelitian serupa oleh Mizwar (2012) yang berjudul "Penentuan lokasi TPA sampah kota Banjarbaru menggunakan sistem informasi geografis, disebutkan bahwa kota Banjarbaru mempunyai 7 lokasi yang layak sebagai TPA. Dalam Penelitian tersebut dipergunakan SNI 03-3241-1994 sebagai dasar kriteria utama dan menentukan 8 (delapan) parameter utama sebagai penentu kelayakan regional.

Metode yang digunakan pada tahap regional menggunakan sistem Binary sehingga lokasi langsung tersaring menjadi 2 kategori yaitu layak dan tidak layak. Selanjutnya Mizwar (2012) mengunakan metode Analytical Hierarchy Process (AHP) dan Weighted Linear Combination (WLC) untuk menentukan tingkat kesesuaian lahan dari beberapa alternatif lokasi yang telah diperoleh pada penilaian tahap pertama berdasarkan tujuh kriteria penilaian kelayakan penyisih. AHP digunakan untuk menentukan bobot dan nilai dari masing-masing kriteria penilaian, sedangkan WLC digunakan untuk operasi perhitungan nilai kesesuaian sebagai lokasi TPA. Hasilnya adalah 5 tingkat kriteria yaitu sangat rendah, rendah, sedang, tinggi dan sangat tinggi.

Evaluasi kelayakan yang dilakukan dalam penelitian ini melakukan proses terbalik dari peneliti terdahulu, yaitu dengan melakukan akumulasi skoring dan pengharkatan pada tahap pertama dan dilakukan penyisihan dengan melakukan buffering dan penyisihan terhadap lokasi yang tidak dapat dijadikan lokasi TPA.

\subsection{Aspek Penentu dalam Evaluasi Kelayakan TPA kota Palangka Raya}

Evaluasi kelayakan untuk TPA berdasarkan aspek geologi lingkungan dapat digunakan pada tahap regional, hal ini dapat disesuaikan dengan tahap regional sesuai SNI 03-3241-1994. Kriteria yang digunakan untuk tahapan regional sesuai SNI 03-3241-1994 adalah sebagai berikut:

1. Kondisi geologi, yang mana tidak berlokasi di zona Holocene Fault (sesar) dan tidak boleh berada di zona bahaya geologi.

2. Kondisi Hidrogeologi tidak boleh mempunyai muka air tanah kurang dari 3 meter, tidak mempunyai kelulusan tanah (permeabilitas) lebih besar dari $10^{-6}$ $\mathrm{cm} /$ det, serta mempunyai jarak terhadap sumber air minum lebih besar dari 100 meter di hilir aliran.
3. Kemiringan lereng harus kurang dari $20 \%$.

4. Jarak terhadap lapangan terbang harus lebih besar dari 3.000 meter.

5. Tidak boleh pada daerah lindung/cagar alam dan daerah banjir dengan periode ulang 25 tahun.

Permasalahan utama dari sebuah lokasi TPA adalah berupa polusi air tanah atau biasa disebut dengan air lindi (leachate). Air lindi atau leachate adalah suatu cairan yang dihasilkan dari pemaparan air hujan pada timbunan sampah. Cairan ini sangat berbahaya karena mengandung konsentrasi senyawa organik maupun senyawa anorganik tinggi, yang terbentuk dalam landfill akibat adanya air hujan yang masuk ke dalamnya (Munawar, 2011). Sehingga faktor utama dalam pemilihan lokasi sebuah TPA sampah sebaiknya adalah pemilihan yang mempertimbangkan kondisi fisik dasar yang menitikberatkan pada pengurangan resiko bencana dan pencemaran.

Dalam mempertimbangkan kondisi fisik dasar yang menitikberatkan pada pengurangan resiko bencana dan pencemaran maka faktor geologi, hidrologi/Hidrogeologi dan topografi adalah faktor utama yang menentukan dalam pemilihan lokasi TPA Sampah.

Ketiga faktor utama dalam penentuan lokasi TPA Sampah merupakan pemenuhan kriteria kesesuaian fisik aspek geologi lingkungan dan memenuhi pesyaratan utama SNI 03-3241-1994 yang menghasilkan zona kelayakan pada tingkat regional. Selain tiga faktor utama tersebut, faktor lain yang juga berpengaruh dalam penentuan lokasi TPA adalah curah hujan, daerah-daerah yang rawan terjadi gerakan tanah atau erosi serta pengunaan lahan yang terkait dengan tumbuhtumbuhan yang ada di dalamnya.

Berdasarkan peta geologi lembar Palangka Raya (Nila, 1995) dapat dilihat bahwa di kota Palangka Raya tidak ditemukan struktur geologi yang berkembang seperti sesar (zona Holocene Fault) maupun jejak kekar/retakan atau penampakan lahan seperti pembelokan sungai, pergeseran sungai, pembelokan pegunungan, gawir sesar yang merupakan ciri-ciri penanda suatu daerah yang mempunyai zona sesar aktif. Sehingga faktor pembatas pada aspek geologi lingkungan sama sekali tidak berpengaruh dalam penentuan zona kelayakan TPA. Sebaliknya faktor pembatas non geologi, yang sangat berperan dalam menentukan zona kelayakan TPA di kota Palangka Raya.

\subsection{Review TPA Sampah Kota Palangka Raya existing terhadap hasil Evaluasi kelayakan berdasarkan Aspek Geologi Lingkungan.}

Lokasi TPA Sampah kota Palangka Raya existing berada sekitar 14 kilometer dari pusat kota dan mempunyai jarak 650 meter dari jalan utama Tjilik Riwut. Hasil laboratorium tanah di lokasi disajikan pada Tabel 18. 
Tabel 18. Hasil laboratorium analisa fisik Tanah di lokasi TPA Existing

\begin{tabular}{cccccc}
\hline No & $\begin{array}{c}\text { Berat Jenis } \\
\text { Tanah }\end{array}$ & $\begin{array}{c}\text { Kadar air } \\
\text { Tanah (\%) }\end{array}$ & $\begin{array}{c}\text { Derajat } \\
\text { Kejenuhan (\%) }\end{array}$ & Porositas & Klasfikasi USCS \\
\hline 1 & 2,577 & 17,25 & 68,13 & 39,49 & SP (poorly graded sand with gravel) \\
2 & 2,584 & 19,18 & 65,51 & 43,07 & SP (poorly graded sand with gravel) \\
\hline
\end{tabular}

Hasil laboratorium memperlihat lokasi TPA Sampah existing berdasarkan klasifikasi USCS adalah pasir yang mempunyai gradasi yang buruk. Berdasar tabel permeabilitas berdasarkan klasifikasi tanah oleh Look (2007) Pasir bergradasi buruk dengan klasifikasi USCS mempunyai kisaran nilai permeabilitas antara $10^{-4}-10^{-2}$ $\mathrm{m} /$ det atau 0,1-1 cm/det. Bila berdasarkan SNI 03-32411994 lokasi maka nilai kelulusan tanah (permeabilitas) suatu lokasi TPA sebaiknya tidak lebih besar dari $10^{-6} \mathrm{~cm} /$ det.

Berdasarkan hasil overlay lokasi TPA sampah yang ada dengan peta hasil evaluasi lahan berdasarkan aspek penentu utama pada tahap regional yaitu aspek geologi lingkungan berada di zona layak rendah, dimana faktor yang mempengaruhinya adalah aspek litologi yang berada di Formasi Dahor. Formasi dahor di dominasi oleh pasir dengan fragmen berupa konglomerat coklat kehitaman, batupasir, batulempung, batulempung karbonan. Selain itu aspek Hidrogeologi juga memberikan kontribusi lokasi TPA existing berada pada zona layak rendah, yaitu berada pada kontur air tanah berkisar antara 20-15 meter di atas muka air laut, serta curah hujan yang mencapai $4.200 \mathrm{~mm} /$ tahun. Muka air tanah pada sumur pantau yang berjarak 100 meter dari TPA sampah berada pada kedalaman 11,5 meter.

Hasil overlay dengan aspek pembatas dalam tahap penyisih, lokasi TPA sampah kota Palangka Raya berada pada zona tidak layak. Hal ini disebabkan karena lokasi berada sangat dekat dengan area pemukiman yang ada yaitu berjarak kurang dari 150 m. Sesuai SNI SNI 03-3241 lokasi dengan jarak kurang dari 100 meter merupakan zona penyangga berupa sabuk hijau tanaman keras dan perluasan instalasi dan tidak diperuntukan untuk pemukiman.

Dengan bertumbuhnya jumlah penduduk dan terjadinya peningkatan jumlah sampah, lokasi TPA Sampah Palangka Raya existing menjadi tidak ideal secara estetika dan secara fisik dinilai berdasarkan aspek geologi lingkungan lokasi TPA Sampah Kota Palangka Raya berada di zona layak rendah.

\section{KESIMPULAN DAN SARAN}

Hasil evaluasi kelayakan berdasarkan aspek geologi lingkungan untuk penentuan lokasi TPA Kota Palangka Raya adalah disimpulkan sebagai berikut:

Pertama, kota Palangka Raya memiliki 3 (tiga) zona kelayakan lahan untuk TPA, yaitu zona tidak layak seluas
$165.936,69$ ha atau $58,12 \%$ dari luas total, zona layak rendah seluas $25.788,88$ ha atau $9,03 \%$ dan zona layak sedang seluas $93.782,25$ ha atau $32,85 \%$. Zona tidak layak sebagai lokasi TPA, meliputi daerah kecamatan sebangau, Pahandut dan sebagian Jekan Raya sedangkan zona yang layak untuk menjadi TPA sampah meliputi daerah pada kecamatan Bukit Batu, Rakumpit dan sebagian kecil Jekan Raya dan Pahandut. 2

Kedua, terdapat 6 (enam) aspek geologi lingkungan dan 2 (dua) Aspek Pembatas yang digunakan pada tahap penentuan lokasi TPA kota Palangka Raya, yaitu: (a) aspek Geologi Lingkungan berupa formasi geologi (litologi), Topografi (kelerengan), Hidrogeologi (kontur Air tanah), Curah hujan, Potensi gerakan tanah, Penggunaan lahan; (b) aspek pembatas yaitu aspek pembatas geologi, berupa Zona Sesar Aktif, Zona Bahaya Gunung Api dan jarak dari garis pantai tidak diperhitungkan dalam penentuan lokasi TPA kota Palangka Raya. Hal ini disebabkan secara geologi, kota Palangka Raya mempunyai faktor-faktor geologi yang tidak terlalu rumit dan cendrung homogen.

Aspek pembatas non geologi, berupa kawasan lindung, Jarak terhadap pemukiman, jarak terhadap jalan utama, jarak terhadap bandara, daerah rawan banjir berkala, Jarak terhadap sungai dan danau (termasuk jaringan irigasi/ drainase dan jaringan air bersih PDAM) menjadi Aspek pembatas yang menentukan karena dalam perencanaan penentuan lokasi TPA perlu memperhatikan arah perkembangan tata ruang.

Ketiga, review lokasi TPA Sampah Kota Palangka Raya existing terhadap peta hasil evaluasi kelayakan berdasarkan aspek geologi lingkungan dengan menggunakan aplikasi SIG memperlihatkan hasil overlay lokasi TPA sampah berada di zona layak rendah. Selanjutnya bila dilakukan overlay dengan aspek pembatas lokasi TPA sampah kota Palangka Raya berada di zona tidak layak, hal ini disebabkan lokasi berada sangat dekat dengan area pemukiman yang ada yaitu kurang dari $150 \mathrm{~m}$. Lokasi TPA Sampah kota Palangka Raya masuk ke dalam zona buffering, dimana jarak ideal dari area pemukiman adalah lebih dari 300 meter

Selanjutnya, berdasarkan kesimpulan tersebut, disarankan hal-hal sebagai berikut. Pertama, dengan bertumbuhnya jumlah penduduk dan terjadinya peningkatan jumlah sampah, lokasi TPA Sampah Palangka Raya menjadi tidak ideal secara estetika dan secara fisik dinilai berdasarkan aspek geologi lingkungan lokasi TPA Sampah Kota Palangka Raya berada di zona layak rendah dan berdasarkan aspek pembatas berada 
pada zona tidak layak, sehingga perlu dipikirkan untuk mengkaji lokasi baru yang lebih mempunyai penilaian secara fisik maupun sosial ekonomi lebih baik.

Kedua, daerah yang berada dalam zona layak sedang meliputi seluas $93.782,25$ ha atau $32,85 \%$ berada daerah pada kecamatan Bukit Batu, Rakumpit dan sebagian kecil Jekan Raya dan Pahandut, selanjutnya dapat kembali di evaluasi untuk dapat ditetapkan sebagai lokasi TPA dengan melakukan penelitian lebih detil terhadap beberapa lokasi terpilih. Ada beberapa metode yang dapat digunakan pada tahap penetapan salah satunya adalah metode metode Le Grand dan metode Hagerty.

\section{DAFTAR PUSTAKA}

Al-Hanbali, A., Alsaaideh, B., \& Kondoh, A. (2011). Using GIS-based weighted linear combination analysis and remote sensing techniques to select optimum solid waste disposal sites within Mafraq City, Jordan. Journal of Geographic Information System, 3 (4), 267-278.

Badan Pusat Statistik Kota Palangka Raya. (2018). Palangka Raya Dalam Angka 2018, BPS Kota Palangka Raya, Kalimantan Tengah.

Badan Standarisasi Nasional. (1994). SNI 19-3241-1994. Tata Cara Pemilihan Lokasi Tempat Pembuangan Akhir Sampah. Jakarta

Departemen Pekerjaan Umum. (1994). SNI 03-3241-1994 tentang Tata Cara Pemilihan Lokasi Tempat Pembuangan Akhir Sampah. Jakarta.

Eki, A. T. T. (2014). Kajian Geologi Lingkungan Terhadap Penetapan Calon Lokasi TPA Sampah PitayKecamatan Sulamu, Kabupaten Kupang Provinsi Nusa Tenggara Timur. Skripsi. Jurusan Teknik Pertambangan Universitas Nusa Cendana.

Hariyanto, M. H. S., Ramdani, F., \& Saputra, M. C. (2018). Sistem Informasi Geografis Kesesuaian Lahan Perumahan di Kota Malang menggunakan Metode MCE. Jurnal Pengembangan Teknologi Informasi dan Ilmu Kompute. 2(1), 263-272.

Karnawati, D. (2007). Mekanisme Gerakan Massa Batuan Akibat Gempabumi; Tinjauan dan Analisis Geologi Teknik. Jurnal Dinamika Teknik Sipil, 7(2), 179-190.

Karthiheyan, P. N., \& Yeshodha, L. Site Selection for Urban Solid Waste Disposal Using Remote Sensing and Open Source GIS in Krishnagiri District, Tamil Nadu. International Journal for Innovative Research in Science \& Technology, 2(10), 233-239.
Kenate, L. (2017). Suitability Analysis of Solid Waste Disposal Site Using GIS Techniques for Sululta Town: Oromia Special Zone Surrounding Finfinne, Ethiopia (Doctoral dissertation, Addis Ababa University).

Look, B. G. (2007). Handbook of Geotechnical Investigation and Design Tables, London, UK. Taylor \& Francis Group.

Mizwar, A. (2016). Penentuan Lokasi Tempat Pengolahan Akhir (TPA) Sampah Kota Banjarbaru Menggunakan Sistem Informasi Geografis (SIG). EnviroScienteae, 8(1), 16-22.

Munawar, A. (2011). Rembesan Air Lindi (Leachate) Dampak Pada Tanaman Pangan dan Kesehatan. Universitas Pembangunan Nasional Veteran Jawa Timur. Surabaya.

Pusat Air Tanah dan Geologi Lingkungan. (2016). Peta Hidrogeologi Indonesia lembar Palangkaraya, Skala 1: 100.000. Badan Geologi. Bandung.

Pusat Air Tanah dan Geologi Lingkungan. (2016). Peta Hidrogeologi Indonesia lembar Pematang Limau, Skala 1: 100.000.. Badan Geologi. Bandung.

Pusat Air Tanah dan Geologi Lingkungan, 2013. Survei Potensi Air Bawah Tanah di Wilayah Kota Palangka Raya (sebagian kec. Pahandut dan Sebagian Kecamatan Jekan Raya. Kerjasama antara Pusat Air Tanah dan Geologi Lingkungan. Badan Geologi dan Dinas Pertambangan dan Energi Kota Palangkaraya. Palangkaraya.

Pusat Air Tanah dan Geologi Lingkungan, 2013. Peta konservasi Air Tanah cekungan air tanah Palangka Raya-Banjarmasin II, Kalimantan. Skala 1:250.000.

Pusat Air Tanah dan Geologi Lingkungan (2018). Peta Zona Kerentanan Gerakan Tanah Provinsi Kalimantan Tengah. Skala 1:250.000. Pusat Vulkanologi dan Mitigasi Bencana Geologi. Badan Geologi. Bandung.

Şener, Ş., Sener, E., \& Karagüzel, R. (2011). Solid waste disposal site selection with GIS and AHP methodology: a case study in Senirkent-Uluborlu (Isparta) Basin, Turkey. Environmental monitoring and assessment, 173(1-4), 533-554.

Undang-Undang Republik Indonesia Nomor 18 Tahun 2008 tentang Pengelolaan Sampah. (7 Mei 2008). Lembaran Negara Republik Indonesia Tahun 2008 Nomor 69. Jakarta.

Undang-Undang Republik Indonesia Nomor 30 Tahun 2007 tentang Energi. (10 Agustus 2007). Lembaran Negara Republik Indonesia Tahun 2007 Nomor 96. Jakarta. 